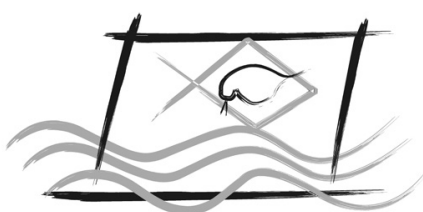

ECOTOX - BRASIL

\title{
Environmental risk assessment of freshwater sediments contaminated with triclosan
}

\author{
Pusceddu, F.H. ${ }^{1,2 *}$; Cortez, F.S. ${ }^{2}$; Santos, A.R. ${ }^{2}$; Pereira, C.D.S. ${ }^{2,3}$; \\ Cesar. A. ${ }^{2,3}$; Choueri, R.B. ${ }^{3} \&$ Bohrer-Morel, M.B. ${ }^{1}$ \\ ${ }^{1}$ IPEN, Instituto de Pesquisas Energéticas e Nucleares da Universidade de São Paulo, Centro de Química e Meio Ambiente, \\ São Paulo, SP, Brasil \\ ${ }^{2}$ UNISANTA, Laboratório de Ecotoxicologia, Universidade Santa Cecília, Santos, São Paulo, Brasil \\ ${ }^{3}$ UNIFESP, Instituto do Mar - Campus Baixada Santista, Universidade Federal de São Paulo, Santos, São Paulo, Brasil
}

(Received September 20, 2016; Accept January 01, 2017)

\begin{abstract}
The purpose of this study was to assess the environmental risk of sediments contaminated with triclosan to thropical aquatic invertebrates. Acute toxicity assays with Chironomus xanthus and chronic toxicity assays with Ceriodaphnia dubia were performed using spiked sediments with environmentally relevant concentrations of triclosan. We obtained a lethal concentration (LC50 96-h) in acute toxicity assays with C. xanthus of $45.26 \mu \mathrm{g} \mathrm{g}^{-1}$ and a no observed effect concentration (NOEC) and lowest observed effect concentration (LOEC) for C. dubia of 5.78 and $6.94 \mu \mathrm{g} \mathrm{g}^{-1}$, respectively. According to equilibrium partitioning theory, these spiked sediment values are equivalent to interstitial water LC50 values of $47.28 \mu \mathrm{g} \mathrm{L}-1$ for C. xanthus and an LOEC of $7.24 \mu \mathrm{g} \mathrm{L}^{-1}$ for $C$. dubia. Our results suggest that sediments contaminated with triclosan represent high risk to freshwater organisms, since this compound has been reported on the order of magnitude of $\mu \mathrm{g} \mathrm{g}^{-1}$ in sediment near discharge of untreated domestic and industrial wastewater.
\end{abstract}

Keywords: Antimicrobial; Ceriodaphnia dubia; Chironomus xanthus; chronic effects; environmental risk assessment; equilibrium partitioning theory; personal care products; spiked sediments.

\section{INTRODUCTION}

Currently, there is an increasing concern about the presence of micropollutants, such as pharmaceutical and personal care products (PPCP), in aquatic environments. Evidence is accumulating that domestic sewage and effluents from pharmaceutical factories could also be carrying drugs into aquatic environments even after passing through wastewaterprocessing facilities (Gilbert, 2011).

Environmental effects of PPCP include the feminization of fish by contraceptive pill residues and the deaths of millions of vultures on the Indian subcontinent following ingestion of the anti-inflammatory drug diclofenac (Green et al., 2004). Antibiotic and bactericidal overuse has led to the emergence of resistant pathogenic bacteria, not just in medical settings but also in the wider environment (Depledge, 2011).
Triclosan, 5-chloro-2-(2,4-dichlorophenoxy)phenol (TCS), is widely used because of its antimicrobial activity. It is found in more than 1,000 products, including toothpaste, mouthwash, soaps, shampoos, lotions, deodorants, and various types of materials, such as packaging of foodstuffs, adhesives, toys, paints, shoes, and clothes, among others (USEPA, 2008). Consequently, this compound is one of the major toxic organic pollutants currently found in domestic wastewaters (Farré et al., 2008). TCS is frequently found in environmental surface waters (Lindström et al., 2002; Xie et al., 2008), in sediments in ranges from $\mathrm{pg} \mathrm{g}^{-1}$ to $\mu \mathrm{g} \mathrm{g}^{-1}$ (Zhao et al., 2010; Venkatesan et al., 2012; Sousa et al., 2015), and in human breast milk (Allmyr et al., 2006; Dayan, 2007). In addition, there is some evidence that photodegradation of TCS generates dichlorodibenzo- $p$-dioxin (DCDD) as a byproduct (Lores et al., 2005), which further increases concern over the extensive use of this substance. 
Several studies have reported its effects of TCS in aquatic organisms. Orvos et al. (2002) investigated TCS toxicity in freshwater algae, daphnids and fish and showed effective concentrations ranging from 1.4 to $390 \mu \mathrm{g} \mathrm{L}^{-1 \text {, while }}$ Ciniglia et al. (2005) found geno and cytotoxicity effects at $250 \mu \mathrm{g} \mathrm{L}^{-1}$. Cortez et al. (2012) observed biological effects from TCS on marine mussels at environmentally relevant concentrations on the order of magnitude of ng L $\mathrm{L}^{-1}$. Using bacteria (Vibrio fischeri) as test organism, triclosan and methyl triclosan have been identified as two of the major organic pollutants currently contributing to the acute toxicity of domestic wastewater (Farré et al., 2008).

Although the knowledge about the effects of PPCPs on freshwater organisms has evolved significantly (e.g. Fent $e t$ al., 2006; Arnold et al., 2014), to date there are few data about the ecotoxicity of such compounds, especially regarding contaminated sediments and benthic biota (Brausch \& Rand, 2011). To our knowledge, few studies have assessed the effects of human PPCPs in freshwater sediments to benthic organisms. Maranho et al. (2014; 2015a) have studied such effects in marine spiked sediments and found that carbamazepine, ibuprofen, fluoxetine, 17 $\alpha$-ethynylestradiol and propranolol inhibits Vibrio fischeri bioluminescence at concentrations ranging from 36.1 to $163.9 \mathrm{ng} \mathrm{g}^{-1}$. The same studies showed effects of these compounds on the embryo-larval development of sea urchins and growth rates of microalgae. Maranho et al. (2015b) also observed lethal and sublethal effects (alterations in cellular energy status, metabolism of monoamines, and inflammation properties) in polychaetes exposed to environmental concentrations of some human pharmaceuticals in marine spiked sediments.

Since TCS tends to accumulate in sediments due to its relative hydrophobicity and half-life in sediments (40 days) (Huang et al., 2015), it is important to understand the effects of this compound on benthic species. It is also important to note that few data exist about triclosan's effects on benthic tropical species. Thus, the knowledge about aquatic toxicity can contribute to the development of international water and sediment quality criteria concerning triclosan.

The aim of this work was to assess the environmental risk of freshwater sediments contaminated with environmentally relevant concentrations of triclosan using aquatic invertebrates Chironomus xanthus, which lives buried in sediments, and Ceriodaphnia dubia that, even if it is not benthic organism, their propensity for inhabiting the sediment-water interface makes them a useful indicator of sediment toxicity, once they feed at the surface of sediments and come into intimate contact with particulate-bound toxicants (Munawar et al., 1999).

\section{MATERIALS AND METHODS}

\section{Test solutions}

TCS $\left(\right.$ Merck $\left.^{\circledR}\right)$ was dissolved in dimethyl sulfoxide (DMSO) $\left(\mathrm{Merck}^{\circledR}\right.$ ) at $40 \mathrm{~g} \mathrm{~L}^{-1}$ before being diluted in freshwater to prepare a stock solution of $100 \mathrm{mg} \mathrm{L}^{-1}$. All test solutions were prepared from this stock solution diluted in reconstituted water from the cultures of each respective test organism. For the definitive tests, five concentrations were used based on the results of the preliminary assays.

To assess the possible effects of the solvent on the test organisms, the highest DMSO concentration used in each experiment was simultaneously tested as the solvent control.

\section{Spiking Sediments}

Spiking involves the addition of one or more chemicals to sediment samples to evaluate the effects of the tested compound. The methods for the preparation, balance and mixture of the spiked sediment with the toxic compound followed the guidelines of the USEPA (2001).

Natural sediment samples were collected near the Broa Reservoir (São Carlos, Brazil). Broa Reservoir is located in the Environmental Protection Area and is free of contamination according to annual monitoring conducted by the Environmental Agency of the State of São Paulo (CETESB, 2010). The sediments were calcined at $550{ }^{\circ} \mathrm{C}$ for 2 hours to eliminate organic compounds that could interfere with TCS toxicity.

Before the spiking procedure, humus was added to the sediment in a proportion of $2 \% \pm 0.5 \%$ as a source of organic carbon, since it has been successfully used for sediment toxicity tests according to the USEPA (2001). The used technique is called "slurry spiking" and consists of placing $250 \mathrm{~g}$ (dry weight) of the sediment sample in a $500 \mathrm{~mL}$ Becker flask and adding $25 \mathrm{~mL}$ of TCS solution in the desired concentration. The control (unspiked) sediment received 25 $\mathrm{mL}$ of deionized water. The mixture of sediment and TCS solution was vigorously shaken for $60 \mathrm{~s}$ twice daily for 7 days under controlled temperature $\left(4 \pm 1{ }^{\circ} \mathrm{C}\right)$ in the dark (Francis et al., 1984).

Following the spiking procedure, dilution water was added to the spiked sediment at a 1:4 ratio of sediment to water. The test bottle was placed in an incubator $\left(25 \pm 1{ }^{\circ} \mathrm{C}\right)$ for 24 hours before beginning the assays.

\section{Toxicity assays}

Acute and chronic toxicity assays were performed with C. xanthus and C. dubia, respectively. The culturing of $C$. xanthus is detailed in ASTM (2005) while the C. dubia cultures procedures were followed the Brazilian standard NBR 13373 (ABNT, 2010). Three experiments were carried out with each species. For both assays, each test vessel contained $5 \mathrm{~g}$ of five different concentrations of spiked sediments with TCS to C. xanthus $\left(24.11-28.93-34.72-41.66-50.0 \mu \mathrm{g} \mathrm{g}^{-1}\right)$ and C. dubia $\left(4.82-5.78-6.94-8.33-10.0 \mu \mathrm{g} \mathrm{g} \mathrm{g}^{-1}\right)$, and $20 \mathrm{~mL}$ of overlaying water and one individual was added to each test vessel. Ten replicates were performed for each test concentration in each experiment.

Acute toxicity assays with $C$. xanthus using spiked sediments were performed following ASTM (2005) 
procedures, with the minor adaptations proposed by Fonseca \& Rocha (2004) concerning 96-h exposure time. The assay consisted of exposing 7-day-old C. xanthus larvae (second to third instar) to test solutions and evaluating survival after $96 \mathrm{~h}$. The assays were maintained under a controlled temperature of $25 \pm 1{ }^{\circ} \mathrm{C}$ and a 16 -h light photoperiod. Chironomus xanthus larvae were fed on days 0 and 2 of the assay with $0.25 \mathrm{~g} \mathrm{~L}^{-1}$ TetraFin $^{\circledR}$. The test acceptability for C. xanthus is based on $90 \%$ control survival.

The chronic toxicity assays of sediments with C. dubia were performed following the recommendations of Burton \& Macpherson (1995) and ASTM (2005). The assay method consisted of evaluating the reproductive performance of $C$. dubia $(<24 \mathrm{~h}$ old) exposed to the test solutions for 7 days, by means of quantifying the number of neonates after exposure time. Test acceptability for $C$. dubia a minimum mean control survival of $\geq 80 \%$, average brood size per surviving females in control must be $\geq 15$ for tests.

Test vessels were maintained in a 16:8-h light-dark photoperiod at $25 \pm 2{ }^{\circ} \mathrm{C}$. The dilution water was adjusted to $\mathrm{pH}$ 7.3. Ceriodaphnia dubia were fed a daily diet of Pseudokirchneriella subcapitata $\left(2 \times 10^{5}\right.$ cells $\left.\mathrm{mL}^{-1}\right)$.

\section{Statistics}

The Trimmed Spearman-Karber method was used to calculate the 96-h LC50 in the acute assays. The data in the chronic assays were first analyzed for normality using Chi-square $\left(x^{2}\right)$ (goodness of fit) test and Bartlett's test for homoscedasticity. Student's $t$-test was employed to identify significant differences between controls and the highest concentration of the solvent DMSO in each assay. We used ANOVA followed by Dunnett's test to identify concentrations of TCS that differed significantly from the control and to establish the NOEC (no observed effect concentration) and LOEC (lowest observed effect concentration) for each chronic toxicity assay. Statistical significance was set at 0.05 , and the statistical analyses were performed with TOXSTAT 3.5 (West \& Gulley, 1996).

\section{Environmental risk assessment}

The environmental risk assessment posed by triclosan on aquatic sediments was assessed through the calculation of risk quotients (RQ) according to the European Guidelines (EC, 2003; EMEA, 2006). RQ values for aquatic organisms were calculated from the measured environmental concentration (MEC) obtained from Sousa et al. (2015) and the predicted no effect concentration (PNECs) of triclosan. PNECs are calculated by dividing the LC50 value and the lowest chronic no observed effect concentrations (NOECs) by assessment factors (AFs), according to the Equation (1 and 2). A commonly used risk ranking criteria was applied: RQ $<0.1$ means minimal risk, $0.1 \leq \mathrm{RQ}<1$ means median risk, and $\mathrm{RQ}$ $\geq 1$ means high risk.

$$
\begin{aligned}
& \text { PNEC }=\frac{\text { EC50 }}{1000} \\
& \text { PNEC }=\frac{\text { CENO }}{10}
\end{aligned}
$$

\section{RESULTS AND DISCUSSION}

\section{Spiked-sediment toxicity assays}

The 96-h LC50 observed in the acute toxicity assays with C. xanthus ranged from 41.66 to $50.00 \mu \mathrm{g} \mathrm{g}^{-1}$, with a mean value of $45.26 \pm 4.29 \mu \mathrm{g} \mathrm{g}^{-1}$ and a coefficient of variation of $9 \%$ (Table 1). These results were more sensitive than obtained from Perron et al. (2012), which showed acute toxicity of TCS spiked sediments on estuarine amphipoda Ampelisca abdita and mysid Americamysis bahia. After 7-d exposure, the lethal concentration to amphipoda $A$. abdita and mysid A. bahia were 303 and $257 \mu \mathrm{g} \mathrm{g}^{-1}$, respectively.

Such TCS concentration is many times higher than current environmental levels found in sediments (ranging around 0.1 to $1.3 \mu \mathrm{g} \mathrm{g}^{-1}$ in highly contaminated sites) (Zhao et al., 2010; Venkatesan et al., 2012; Sousa et al., 2015). However, such results do not imply that current environmental levels of TCS are safe to benthic aquatic organisms. Organisms in the environment are subjected to a mixture of contaminants that may act synergistically. Farré et al. (2008) reported synergism between TCS and surfactants commonly found in domestic sewage. It is important to consider that organisms can also be exposed to other pathways such as when feeding. Coogan et al. (2007) observed the bioaccumulation of TCS by algae, which are important food source to many aquatic organisms. In addition, sublethal effects, such as growth, reproductive performance or mouthpart deformity in larval stages may occur at lower concentrations than those found for lethality.

Reproductive performance was evaluated for C. dubia and the NOEC and LOEC of TCS for were 5.78 and $6.94 \mu \mathrm{g}$ $\mathrm{g}^{-1}$, respectively (Fig. 1). These values are in the same order of magnitude as the environmental concentrations of TCS in sediments. Considering that the use of TCS have been increasing over the last years, and this compound persists and accumulates in sediments (Cantwell et al., 2010; Huang et al., 2015), environmental levels can reach $C$. dubia's LOEC for reproduction. The high octanol/water partition coefficient $\left(\mathrm{K}_{\mathrm{ow}}=4,76\right)$ of TCS indicate uptrend adsorption of this compound on organic matter and accumulation in biota and sediment. According to Barel-Cohen et al. (2006), though

Table 1 - Results of acute toxicity assays $(\mathrm{n}=3)$ with Chironomus xanthus (LC50).

\begin{tabular}{lcc}
\hline Assay & $\mathrm{LC}^{2} 0 \mu \mathrm{g} \mathrm{g}^{-1}$ & Confidence limits-95\% (lower-upper) \\
\hline 1 & 41.66 & $(35.09-49.47)$ \\
2 & 50.00 & $(50.00-50.00)$ \\
3 & 44.11 & $(37.11-52.42)$ \\
Mean & 45.26 & - \\
SD & 4.29 & - \\
\hline
\end{tabular}




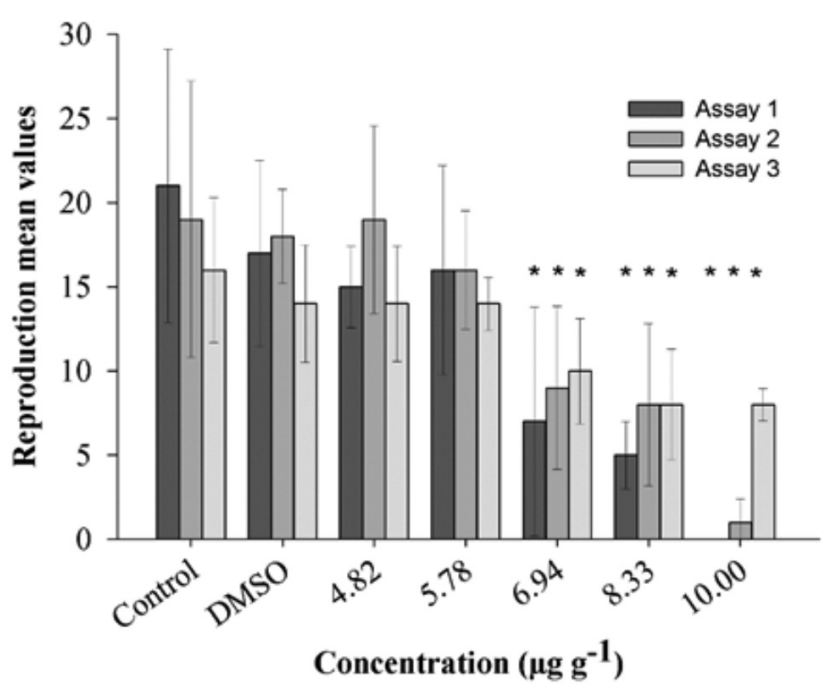

Fig. 1 Results of chronic toxicity assays with C. dubia $(\mathrm{n}=3)$ in spiked sediments $\left(\mu \mathrm{g} \mathrm{g}^{-1} ;\right.$ mean $\left.\pm \mathrm{SD}\right)$. An asterisk indicates a significant difference from the control (ANOVA-Dunnett's test, $\mathrm{p}<0,05$ )

PPCPs concentrations are reduced by half after $25 \mathrm{~km}$ from the discharge of sewage source, the compounds can still be detected more than $100 \mathrm{~km}$ away from the source of rivers.

Recent studies by Perron et al. (2012) and Venkatesan et al. (2012) with spiked sediments, estimated the pore water concentrations based on equilibrium partitioning to determine the effective concentrations in pore water (USEPA, 1993).

This approach uses the organic carbon-normalized solidwater partition coefficient ( $K_{o c} \mathrm{~L} \mathrm{~kg}^{-1}$ organic carbon), the octanol-water partition coefficient $\left(\log _{10} K_{\text {ow }}=4.76\right.$ for TCS $)$, the effective concentration on sediment $\left(C_{\text {sed }} \mu \mathrm{g} \mathrm{g}^{-1}\right)$ and the fraction of organic carbon in sediments $\left(f_{o c} \%\right)$, to estimate the pore water effective concentrations $\left(C_{p w}\right)$ using Equation 3:

$C_{p w}=\frac{C_{\text {sed }}}{K_{o c} \times f_{o c}}$

According to the USEPA (1993), it is widely accepted that $K_{o c}$ can be estimated from $K_{o w}$. The $K_{o c}$ used to calculate the pore water concentration is based on the regression of $\log _{10} K_{o c}$ to $\log _{10} K_{\text {ow }}$ according to Equation 4:

$\log _{10} K_{\text {oc }}=0.00028+0.983 \log 10 \mathrm{Kow}$

Based on the effective concentrations of TCS in the spiked sediments for $C$. xanthus $\left(45.26 \mu \mathrm{g} \mathrm{g}^{-1}\right)$ and C. dubia $(6.94 \mu \mathrm{g}$ $\left.\mathrm{g}^{-1}\right)$, these equations were used to obtain the predicted TCS pore water effective concentrations of $47.28 \mu \mathrm{g} \mathrm{L}^{-1}$ and $7.24 \mu \mathrm{g}$ $\mathrm{L}^{-1}$, respectively. Although these estimations should be used carefully, these estimated values are similar to the effective concentrations obtained in other studies in water for algae (Orvos et al., 2002), fishes (Nassef et al., 2010), amphibians (Palenske et al., 2010) and marine bivalves (Cortez et al., 2012), including the NOEC for C. dubia (Orvos et al., 2002) and C. xanthus (Dussault et al., 2008).

The environmental risk to aquatic organisms in sediments were assessed for the worst case scenario based on the risk quotients (RQ) calculated using maximum MEC reported on previously studies on Brazilian freshwaters sediments (Sousa et al., 2015) and PNECs of present study (Table 2). The RQ values for TCS were 3.91 and 0.30 to C. xanthus and C. dubia, respectively. Whereas the risk classification should be based on the most sensitive result, TCS could pose a high risk to the aquatic organisms in freshwater sediments.

Recently, the European Commission, in the scope of Directive 2013/39/EU, establishes a list of priority chemicals in the field of water policy, which constitute a significant risk to the aquatic environment (EC, 2013). The Commission shall establish a watch list of substances, which includes Diclofenac, 17-beta-estradiol and 17 $\alpha$-ethinylestradiol, in order to gather monitoring data for facilitating the determination of appropriate measures to address the risk posed by those substances. For this, the results of monitoring programmes will be considered as well as research projects, production volumes, use patterns, intrinsic properties (including, where relevant, particle size), concentrations in the environment and effects. According to the results obtained in this study, triclosan should be included in the next review of the adopted watch list of substances, expected to take place no later than four years after the entry into force of this Directive (EC, 2013).

The present study contributed to the understanding of the effects of TCS contaminated sediments on benthic and epibenthic freshwater species. Given the limited knowledge concerning the relationships between the concentrations of pharmaceutical and personal care products (PPCP) in sediments and their bioavailability to aquatic organisms in tropical and subtropical environments, more studies are needed to determine the biological effects, especially sublethal ones, of these contaminants in sediments and to assess the bioavailability of these compounds at environmentally relevant concentrations.

\section{CONCLUSION}

Triclosan caused chronic and acute toxicity to Chironomus xanthus and Ceriodaphnia dubia in concentrations in the same order of magnitude as the environmental concentrations reported in freshwater sediments. In addition, adverse biological effects were observed at environmentally relevant concentrations when the equilibrium partitioning theory was used to estimate pore water concentrations. The obtained results suggest that sediments contaminated with TCS represent high risk to freshwater organisms.

Table 2 - Predicted no effect concentrations (PNECs), maximum measured environmental concentration (MEC) in Brazil (Sousa et al., 2015) and risk quotients (RQs) (maximum MEC/PNEC) of the triclosan.

\begin{tabular}{|c|c|c|c|}
\hline Organism & $\begin{array}{l}\text { PNEC } \\
\left(\mu \mathrm{g} \mathrm{g}^{-1}\right)\end{array}$ & $\begin{array}{l}\text { Maximum MEC } \\
\left(\mu \mathrm{g} \mathrm{g}^{-1}\right)\end{array}$ & $\begin{array}{c}\text { RQs } \\
\text { (maximum MEC/ PNEC) }\end{array}$ \\
\hline C. xanthus & 0.045 & 0.176 & 3.91 \\
\hline C. dubia & 0.58 & 0.176 & 0.30 \\
\hline
\end{tabular}




\section{ACKNOWLEDGMENTS}

This project was supported by CNEN - Comissão Nacional de Energia Nuclear. Cesar, A. and Pereira, C.D.S. thanks to CNPq (Conselho Nacional de Desenvolvimento Científico e Tecnológico, MEC - Brazil) for the research productivity scholarships (PQ\#305869/2013-2 and PQ\#307074/2013-7, respectively).

\section{REFERENCES}

ABNT - Associação Brasileira de Normas Técnicas. 2010. NBR 13373. Ecotoxicologia aquática - Toxicidade crônica aguda Método de ensaio com Ceriodaphnia spp (Crustacea, cladocera). Rio de Janeiro.

ALLMYR, M., ADOLFSSON-ERICI, M., MCLACHLAN, M.S., SANDBORGH-ENGLUND, G. 2006. Triclosan in plasma and milk from Swedish nursing mothers and their exposure via personal care products. Sci. Total Environ., 372:87-93. http:// dx.doi.org/10.1016/j.scitotenv.2006.08.007

ARNOLD, K.E., BROWN, A.R., ANKLEY, G.T., SUMPTER, J.P. 2014. Medicating the environment: assessing risks of pharmaceuticals to wildlife and ecosystems. Philos. Trans. R. Soc. B B, 369:20130569. DOI: 10.1098/rstb.2013.0569

ASTM. 2005. Standard Test Method for Measuring the Toxicity of Sediment-Associated Contaminants with Freshwater Invertebrates. American Society of Testing and Materials E 1706-05.

BAREL-COHEN, K., SHORE, L.S., SHEMESH, M., WENZEL, A., MUELLER, J., KRONFELD-SCHOR, N. 2006. Monitoring of natural and synthetic hormones in a polluted river. J. Environ. Manage., 78:16-23. http://dx.doi.org/10.1016/j. jenvman.2005.04.006

BRAUSCH, J.M., RAND, G.M. 2011. A review of personal care products in the aquatic environment: Environmental concentrations and toxicity. Chemosphere, 82:1518-1532. http:// dx.doi.org/10.1016/j.chemosphere.2010.11.018

BURTON JR., G.A. \& MACPHERSON, C. 1995. Sediment Toxicity Testing Issues and Methods. In HOFFMAN, D.J., RATTNER, B.A., BURTON JR., G.A., CAIRNS JR., J. Handbook of Ecotoxicology, Lewis Publishers, pp 755.

CANTWELL, M.G., WILSON, B.A., ZHU, J., WALLACE, G.T., KING, J.W., OLSEN, C.R., BURGESS, R.M., SMITH, J.P. 2010. Temporal trends of triclosan contamination in dated sediment cores from four urbanized estuaries: Evidence of preservation and accumulation. Chemosphere, 78:347-352. http://dx.doi.org/10.1016/j.chemosphere.2009.11.021

CETESB. 2010. Qualidade das águas superficiais no Estado de São Paulo. Série Relatórios. Companhia Ambiental do Estado de São Paulo.

CINIGlia, C., CASCONE, C., GIUDICE, R.L., PINTO, G., POLLIO, A. 2005. Application of methods for assessing the genoand cytotoxicity of Triclosan to C. ehrenbergii. J. Hazard Mater., 122:227-232. http://dx.doi.org/10.1016/j.jhazmat.2005.03.002

COOGAN, M.A., EDZIYIE, R.E., LA POINT, T.W., VENABLES, B.J. 2007. Algal bioaccumulation of triclocarban, triclosan, and methyl-triclosan in a North Texas wastewater treatment plant receiving stream. Chemosphere, 67:1911-1918. http://dx.doi. org/10.1016/j.chemosphere.2006.12.027

CORTEZ, F.S., PEREIRA, C.D.S., SANTOS, A.R., CESAR, A., CHOUERI, R.B., MARTINI, G.A., BOHRER-MOREL, M.B. 2012. Biological effects of environmentally relevant concentrations of the pharmaceutical Triclosan in the marine mussel Perna perna (Linnaeus, 1758). Environ. Pollut., 168:145150. http://dx.doi.org/10.1016/j.envpol.2012.04.024

DAYAN, A.D. 2007. Risk assessment of triclosan [Irgasan ${ }^{\circledR}$ ] in human breast milk. Food. Chem. Toxicol., 45:125-129. http:// dx.doi.org/10.1016/j.fct.2006.08.009

DEPLEDGE, M. 2011. Pharmaceuticals: Reduce drug waste in the environment. Nature, 478:36. doi:10.1038/478036a

DUSSAULT, È.B., BALAKRISHNAN, V.K., SVERKO, E., SOLOMON, K.R., SIBLEY, P.K. 2008. Toxicity of human pharmaceuticals and personal care products to benthic invertebrates. Environ. Toxicol. Chem., 27(2):425-432. doi: 10.1897/07-354R.1.

EC - European Commission. 2003. Technical Guidance Document in Support of Commission Directive 93/67/EEC on Risk Assessment for New Notified Substances and Commission Regulation (EC) No 1488/94 on Risk Assessment for Existing Substances, Part II. Brussels, Belgium.

EC - European Commission. 2013. Directive 2013/39/UE of the European Parliament and of the Council of 12 August 2013, amending Directives 2000/60/EC and 2008/105/EC as regards priority substances in the field of water policy. Official Journal of the European Union.

EMEA - European Medicines Evaluation Agency. 2006. European agency for the evaluation of medicinal products. Committee for medicinal products for human use (CHMP). Guideline on the environmental risk assessment of medicinal products for human use. Ref EMEA/CRMP/SWP/4447/00. London, UK.

FARRÉ, M., ASPERGER, D., KANTIANI, L., GONZÁLEZ, S., PETROVIC, M., BARCELÓ, D. 2008. Assessment of the acute toxicity of triclosan and methyl triclosan in wastewater based on the bioluminescence inhibition of Vibrio fischeri. Anal. Bioanal. Chem., 390:1999-2007. DOI: 10.1007/s00216-007-1779-9

FENT, K., WESTON, A.A., CAMINADA, D. 2006. Ecotoxicology of human pharmaceuticals. Aquat. Toxicol., 76:122-59. http:// dx.doi.org/10.1016/j.aquatox.2005.09.009

FONSECA, A.L., ROCHA, O. 2004. Laboratory cultures of the native species Chironomus xanthus Rempel, 1939 (DipteraChironomidae). Acta. Limnol. Bras., 16:153-161.

FRANCIS, P.C., BIRGE, W.J., BLACK, J.A. 1984. Effects of Cadmium-Enriched Sediment on Fish and Amphibian Embryo-Larval Stages. Ecotoxicol. Environ. Saf., 8:378-387. doi:10.1016/0147-6513(84)90006-X

GILBERT, N. 2011. Drug waste harms fish. Nature, 476:265. doi: $10.1038 / 476265 a$.

GILROY, È.A.M., BALAKRISHNAN, V.K., SOLOMON, K.R., SVERKO, E., SIBLEY, P.K. 2012. Behavior of pharmaceuticals in spiked lake sediments - Effects and interactions with benthic invertebrates. Chemosphere, 86:578-584. http://dx.doi. org/10.1016/j.chemosphere.2011.10.022

GREEN, R.E., NEWTON, I., SHULTZ, S., CUNNINGHAM, A.A., GILBERT, M., PAIN, D., PRAKASH, V. 2004. Diclofenac poisoning as a cause of vulture population declines across the Indian subcontinent. J. Appl. Ecol., 41:793-800. DOI: 10.1111/j.0021-8901.2004.00954.X

HUANG, X., WU, C., HU, H., YU, Y., LIU, J. 2015. Sorption and degradation of triclosan in sediments and its effect on microbes. Ecotox. Environ. Safe., 116:76-83. http://dx.doi.org/10.1016/j. ecoenv.2015.03.002

LINDSTRÖM, A., BUERGE, I.J., POIGER, T., BERGQVIST, P.A., MÜLLER, M.D., BUSER, H.R. 2002. Occurrence and environmental behavior of the bactericide Triclosan and its methyl derivative in surface waters and in wastewater. Environ. Sci. Technol., 36:2322-2329. DOI: 10.1021/es0114254 
LORES, M., LLOMPART, M., SANCHEZ-PRADO, L., GARCIAJARES, C., CELA, R. 2005. Confirmation of the formation of dichlorodibenzo- $p$-dioxin in the photodegradation of triclosan by photo-SPME. Anal. Bioanal. Chem., 381:1294-1298. DOI: 10.1007/s00216-004-3047-6

MARANHO, L.A., BAENA-NOGUERAS, R.M., LARAMARTÍN, P.A., DELVALLS, T.A., MARTÍN-DÍAZ, M.L. 2014. Bioavailability, oxidative stress, neurotoxicity and genotoxicity of pharmaceuticals bound to marine sediments. The use of the polychaete Hediste diversicolor as bioindicator species. Environ. Res., 134:353-365. http://dx.doi.org/10.1016/j. envres.2014.08.014

MARANHO, L.A., GARRIDO-PÉREZ, M.C., DELVALLS, T.A., MARTÍN-DÍAZ, M.L. 2015a. Suitability of Standardized Acute Toxicity Tests for Marine Sediment Assessment: Pharmaceutical Contamination. Water Air Soil Poll., 226:65. DOI: 10.1007/ s11270-014-2273-6

MARANHO, L.A., ANDRÉ, C., DELVALLS, T.A., GAGNÉ, F., MARTÍN-DÍAZ, M.L. 2015b. Toxicological evaluation of sediment samples spiked with human pharmaceutical products: Energy status and neuroendocrine effects in marine polychaetes Hediste diversicolor. Ecotox. Environ. Safe., 118:27-36. http:// dx.doi.org/10.1016/j.ecoenv.2015.04.010

MUNAWAR, M.; DERMOTT, R.; MCCARTHY, L.H.; MUNAWAR, S.F.; VANSTAM, H.A. 1999. A comparative bioassessment of sediment toxicity in lentic and lotic ecosystems of the North American Great Lakes. Aquat. Ecosyst. Health Manag., 2 :367-378.

NASSEF, M., MATSUMOTO, S., SEKI, M., KHALIL, F., KANG, I.J., SHIMASAKI, Y., OSHIMA, Y., HONJO, T. 2010. Acute effects of triclosan, diclofenac and carbamazepine on feeding performance of Japanese medaka fish (Oryzias latipes). Chemosphere, 80:1095-1100. http://dx.doi.org/10.1016/j. chemosphere.2010.04.073

ORVOS, D.R., VERSTEEG, D.J., INAUEN, J., CAPDEVIELLE, M., ROTHENSTEIN, A., CUNNINGHAM, V. 2002. Aquatic toxicity of Triclosan. Environ. Toxicol. Chem., 21:1338-1349. DOI: $10.1002 /$ etc.5620210703

PALENSKE, N.M., NALLANI, G.C., DZIALOWSKI, E.M. 2010.
Physiological effects and bioconcentration of Triclosan on amphibian larvae. Comp. Biochem. Physiol., Part C: Toxicol. Pharmacol., 152(2):232-240. http://dx.doi.org/10.1016/j. cbpc.2010.04.009

PERRON, M.M., HO, K.T., CANTWELL, M.G., BURGESS, R.M., PELLETIER, M.C. 2012. Effects of triclosan on marine benthic and epibenthic organisms. Environ. Toxicol. Chem., 8:18611866. doi: $10.1002 /$ etc. 1884

SOUSA, D.N.R., GROSSELI, G.M., MOZETO, A.A., CARNEIRO, R.L., FADIN, P.S. 2015. Ultrasound-assisted extraction method for the simultaneous determination of emerging contaminants in freshwater sediments. J. Sep. Sci., 38(19):3454-3460. doi: $10.1002 /$ jssc. 201500644

USEPA. 1993. Technical Basis for Deriving Sediment Quality Criteria for Nonionic Organic Contaminants for the Protection of Benthic Organisms by Using Equilibrium Partitioning. United States Environmental Protection Agency EPA-822-R-93-011.

USEPA. 2001. Technical Manual. Methods for collection, storage and manipulation of sediments for chemical and toxicological analyses. Chapter 5: Sediment Manipulations. United States Environmental Protection Agency.

USEPA. 2008. Registration Eligibility Decision for Triclosan. List B, Case No. United States Environmental Protection Agency 2340:98.

VENKATESAN, A.K., PYCKE, B.F.G., BARBER, L.B., LEE, K.E., HALDEN, R.U. 2012. Occurrence of triclosan, triclocarban, and its lesser chlorinated congeners in Minnesota freshwater sediments collected near wastewater treatment plants. J. Hazard. Mater., 229-230:29-35. doi: 10.1016/j.jhazmat.2012.05.049

XIE, Z., EBINGHAUS, R., FLÖSER, G., CABA, A., RUCK, W. 2008. Occurrence and distribution of triclosan in the German Bight (North Sea). Environ. Pollut., 156:1190-1195. http:// dx.doi.org/10.1016/j.envpol.2008.04.008

WEST, INC GULLEY, D. 1996. TOXSTAT®. Computer Program. Version 3.5. University of Wyoming.

ZHAO, J-L., YING, G-G., LIU, Y-S., CHEN, F., YANG, J-F., WANG, L. 2010. Occurrence and risks of triclosan and triclocarban in the Pearl River system, South China: From source to the receiving environment. J. Hazard. Mater., 179:215-222. http://dx.doi.org/10.1016/j.jhazmat.2010.02.082 